\title{
ANALISIS FAKTOR-FAKTOR YANG MEMPENGARUHI PENDAPATAN USAHATANI KENTANG DI KABUPATEN BENER MERIAH PROVINSI ACEH
}

\author{
ANALYSIS OF FACTORS AFFECTING POTATO FARMING INCOME IN BENER MERIAH \\ DISTRICT PROVINCE OF ACEH
}

\author{
Mawardati $^{1}$ )
}

\begin{abstract}
This study was conducted in a potato farm in Bener Meriah District of Aceh Province from June to August 2013. The purpose of this study was to determine the factors that affect potato farm income in the observation site. The analytical method used is the method of multiple linear regression analysis. The analysis showed that the amount of production, land, labor, capital and the selling price is very significant influence on a potato farm in the area.
\end{abstract}

Keyword : income, farming, potato.

\section{PENDAHULUAN}

Indonesia merupakan salah satu negara berkembang dengan sektor pertanian sebagai sumber pencaharian mayoritas penduduknya. Keberadaan sektor pertanian telah terbukti mampu memperbaiki taraf hidup masyarakat pedesaan, meskipun hal ini belum merata menyentuh pedesaan secara keseluruhan. Kemampuan sektor pertanian dapat ditunjukkan dengan aktivitas dalam meningkatkan pendapatan petani.

Selain itu, hal penting yang harus diperhatikan adalah sektor pertanian juga berperan sebagai penyedia pangan bagi masyarakat. Terkait dengan kondisi tersebut maka peningkatan produksi mutlak harus dilakukan. Peningkatan produksi yang harus seimbang dengan laju pertumbuhan penduduk dapat dicapai melalui peningkatan pengelolaan usahatani secara intensif. Oleh karena itu, pengetahuan tentang cara pengusahaan suatu usahatani mutlak dibutuhkan agar dapat meningkatkan produktifitas serta dapat meningkatkan pendapatan sehingga kesejahteraan petani dapat meningkat.

Kontribusi lainnya dari sektor pertanian adalah sebagai penyumbang terhadap devisa negara dan Produk Domestik Bruto (PDB). Tahun 2010 sebesar 15,3 persen dari total nilai PDB menurut lapangan usaha disumbang oleh sektor pertanian, dimana sektor pertanian menjadi penyumbang PDB kedua terbesar setelah sektor industri pengolahan (BPS 2011a). Dengan demikian, maka tidaklah berlebihan jika pengembangan sektor pertanian harus mendapat perhatian serius dari pemerintah selaku pembuat kebijakan.
Salah satu subsektor pertanian yang memiliki potensi untuk dikembangkan yaitu hortikultura yang terdiri atas sayuran, buah-buahan, florikultura, dan biofarmaka. Hortikultura berperan sebagai sumber pangan, sumber pendapatan masyarakat, penyedia lapangan kerja, dan penghasil devisa. Hal tersebut menjadi alasan bahwa subsektor ini perlu menjadi prioritas pengembangan.

Sayuran merupakan salah satu produk hortikultura yang memiliki potensi besar untuk dikembangkan baik sebagai penghasil devisa maupun sebagai sarana meningkatkan pendapatan petani. Selain sebagai komoditas yang penting dalam memenuhi kebutuhan gizi, sayuran telah memberikan kontribusi PDB sebesar 36,35 persen terhadap subsektor hortikultura pada tahun 2010. Produksi sayuran nasional tercatat mengalami peningkatan rata-rata dari tahun 2006 hingga 2010 sebesar 3,01 persen (Ditjenhorti 2011a). Menurut Ditjenhorti (2012), salah satu komoditas sayuran unggulan nasional yang mendapat prioritas pengembangan oleh pemerintah adalah kentang (Solanum tuberosum L).

Tanaman kentang memiliki prospek dalam menunjang program diversifikasi pangan dan bahan baku industri. Namun dalam perkembangannya, mulai tahun 2006 hingga 2011 produktivitas kentang di Indonesia menunjukkan tren menurun (Ditjenhorti 2012)

Kentang prospektif untuk dikembangkan karena permintaannya terus meningkat sejalan dengan pertumbuhan penduduk, sebagai bahan pangan bergizi tinggi, sebagai bahan baku industri

1) Staf Pengajar Fakultas Pertanian Universitas Malikussaleh 
pengolahan pangan, sebagai komoditas ekspor non migas, dan sebagai sumber pendapatan petani. Kentang menjadi tanaman kedua setelah jagung yang ditanam di banyak negara.

Daerah sentra produksi kentang di Provinsi Aceh adalah di wilayah dataran tinggi gayo (Kabupaten Aceh Tengah dan Kabupaten Bener Meriah) yang terletak pada ketinggian $800-2.600$ $\mathrm{m}$ dari permukaan laut. Kecamatan Bukit merupakan salah satu daerah penghasil kentang terbesar di Kabupaten Bener Meriah. Rata-rata produktivitas kentang di Kabupaten Aceh Tengah dan Kabupaten Bener Meriah termasuk di Kecamatan Bukit selama ini secara agregat hanya 6,91 ton/ha. Ini masih jauh di bawah produktivitas secara nasional yaitu 16,7 ton/ha (Dirjen Hortikultura, 2009). Sementara hasil penelitian/pengkajian potensi dapat mencapai 25-30 ton/ha bila dikelola dengan baik dan varietas yang sesuai (M. Nur H.I, Abdul Azis dan M. Ramlan, 2010).

Permasalahan yang dihadapi petani kentang di Kecamatan Bukit saat ini tidak hanya pada produktivitas yang rendah tetapi petani juga dihadapkan ada harga jual kentang yang selain rendah juga tidak menentu (berfluktuasi). Namun petani kentang di daerah tersebut sampai saat ini tetap semangat melakukan kegiatan usahatani kentang.

\section{METODE PENELITIAN}

\section{Lokasi dan Ruang Lingkup Penelitian.}

Penelitian ini dilakukan di Kecamatan Bukit Kabupaten Bener Meriah Provinsi Aceh. Alasan penentuan lokasi penelitian adalah karena Kecamatan Bukit merupakan salah satu daerah sentra produksi kentang di Kabupaten Bener Meriah, namun rata-rata produktivitas kentang masih tergolong rendah dan harga jual berfluktuasi yang berakibat kepada pendapatan petani yang tidak menentu. Ruang lingkup penelitian ini hanya terbatas pada faktor yang mempengaruhi pendapatan petani kentang.

\section{Metode Penarikan Sampel.}

Populasi dalam penelitian ini adalah seluruh petani kentang yang ada di Kecamatan Bukit Kabupaten Bener Meriah. Oleh karena tidak ada data yang akurat tentang jumlah petani kentang maka jumlah sampel dalam penelitian ini ditentukan dengan metode berjatah (quota sampling) yaitu sebanyak 30 orang petani. Selanjutnya untuk menentukan petani sampel dalam penelitian ini digunakan teknik bola salju (snowball sampling) yaitu suatu metode pengambilan sampel dimana sampel pertama akan menentukan sampel selanjutnya.

\section{Jenis dan Sumber Data}

Data yang digunakan dalam penelitian ini adalah data skunder dan data primer. Data skunder diperoleh dari instansti terkait yaitu dari BPS, Dinas Pertanian Kabupaten Bener Meriah dan Kantor Camat Kecamatan Bukit. Data primer diperoleh di lokasi penelitian melalui pengisian kuisioner oleh responden.

\section{Metode Analisis Data}

Metode analisis yang digunakan dalam penelitian ini adalah metode deskriptif kuantitatif. Untuk mengetahui tentang karakteristik petani dan hubungannya dengan pendapatan digunakan analisis deskriptif. Sedangkan untuk menganalisis hubungan antara variabel independen dengan variabel dependen digunakan analisis linear berganda. Secara matematis analisis linear berganda dapat ditulis sebagai berikut :

$Y=\alpha+\beta_{1} X_{1}+\beta_{1} X_{1}+\beta_{1} X_{1}+\beta_{1} X_{1}+\beta_{1} X_{1}+\beta_{1} X_{1}+\beta_{1} X_{1}+\varepsilon$

Keterangan :

$\mathrm{X}_{1}=$ Jumlah produksi $(\mathrm{Kg})$

$\mathrm{X}_{1}=$ luas lahan ( ha)

$\mathrm{X}_{1}=$ Tenaga kerja (HOK)

$\mathrm{X}_{1}=$ Modal (Rp)

$\mathrm{X}_{1}=\operatorname{Harga}(\mathrm{Rp})$

$\varepsilon=$ error term

$\alpha, \beta_{1}, \beta_{1}, \beta_{1}, \beta_{1}, \beta_{1}=$ parameter yang dicari

Model pada persamaan di atas dianalisis untuk mengetahui signifikansi variabel independen dengan variabel dependen. Tingkat signifikansi tersebut dapat dilihat pada nilai $\rho$-value variabel tersebut baik secara individual (t-test) maupun secara bersama-sama atau serentak (F-test).

\section{Definisi Operasional Variabel}

1. Pendapatan $(\mathrm{Y})$ adalah pendapatan yang diterima oleh petani kentang dari penjualan kentang di hitung dalam rupiah per musim tanam ((Rp/MT). 
2. Produksi (Prod) adalah jumlah kentang yang dihasilkan oleh petani dihitung dalam kilogram per musim tanam $(\mathrm{Kg} / \mathrm{MT})$

3. Luas lahan (Lh) adalah luas lahan yang ditanami kentang dihitung dalam hektar per musim tanam (hektar/MT).

4. Tenaga kerja (Tk) adalah jumlah orang yang bekerja pada kegiatan usahatani kentang dihitung dalam Hari Orang Kerja (HOK).

5. Modal (M) adalah jumlah biaya yang dikeluarkan dalam kegiatan usahatani kentang dihitung dalam rupiah per musim tanam (Rp/MT).

6. Harga (Hrg) harga jual kentang di lokasi pada saat penelitian dilakukan dihitung dalam rupiah per kilogram $(\mathrm{Rp} / \mathrm{kg})$.

\section{HASIL PENELITIAN DAN PEMBAHASAN}

\section{Pendapatan Usahatani Kentang}

Pendapatan usahatani merupakan penerimaan yang diperoleh petani dari kegiatan usahataninya. Hasil penelitian menunjukkan bahwa pendapatan tertinggi yang diperoleh petani dari usahatani kentang di lokasi penelitian adalah Rp. 11.809.000,- pendapatan terendah adalah $\mathrm{Rp}$. 2.789.000,- dan pendapatan rata-rata adalah sebesar Rp. 5.813.386,667 per 0,95 hektar atau Rp. 6.414.771,494 per hektar per musim tanam. Jumlah ini belum termasuk biaya tenaga kerja baik tenaga kerja luar keluarga maupun tenaga kerja dalam keluarga. Jumlah pendapatan usahatani kentang ini masih tergolong rendah, hal ini disebabkan sampai saat ini rata-rata produktivitas kentang di lokasi penelitian masih jauh dibawah rata-rata potensial. Selain itu usahatani kentang bukan merupakan satusatunya jenis usaha yang dilakukan oleh petani di lokasi penelitian, sebagian diantara mereka masih memiliki usahatani lainnya. Kondisi ini berakibat kepada kurang maksimalnya pengelolaan terhadap usahatani kentang.

\section{Faktor-faktor yang Mempengaruhi Pendapatan Usahatani kentang.}

\section{Produksi}

Produksi merupakan hasil akhir yang diperoleh dari suatu proses produksi. Produksi kentang diperoleh dari kegiatan mengkombinasikan faktor-faktor produksi seperti lahan, tenaga kerja, modal dan manajemen. Besar kecilnya produksi kentang sangat mempengaruhi terhadap pendapatan usahatani kentang. Rata-rata produksi kentang di lokasi penelitian hanya 3,433 ton per luas tanam atau 3,788 ton per hektar per musim tanam.

\section{Luas Lahan}

Lahan merupakan pabriknya produksi pertanian (Soekartawi, 2002). Besar kecilnya luas lahan sangat berpengaruh terhadap produksi pertanian dan pendapatan usahatani. Luas lahan tertinggi yang diusahakan oleh petani kentang di lokasi penelitian adalah 1,075 hektar, terendah 0,825 hektar dan rata-rata 0,906 hektar. Rata-rata luas tanam suatu usahatani di bawah 1 hektar belum memenuhi skala ekonomis.

\section{Tenaga Kerja}

Jumlah tenaga kerja yang digunakan dalam suatu kegiatan usahatani sangat berpengaruh terhadap pendapatan usahatani tersebut. Apalagi jika yang digunakan lebih banyak tenaga kerja luar keluarga berarti akan memperbesar biaya tunai yang harus dikeluarkan oleh petani. Rata- rata jumlah tenaga kerja yang digunakan dalam usahatani kentang di lokasi penelitian adalah 30,28 HOK per luas tanam atau 33,85 HOK per hektar per musim tanam. Sebahagian besar tenaga kerja ini berasal dari dalam keluarga petani itu sendiri dan hanya sebagian kecil saja yang berasal dari luar keluarga.

\section{Modal}

Modal yang dimaksudkan dalam penelitian ini adalah jumlah biaya variabel yang digunakan petani dalam suatu proses produksi. Besar kecilnya jumlah modal yang dimiliki petani akan berpengaruh kepada pendapatan yang diperolehnya. Rata-rata jumlah modal yang digunakan oleh petani dalam usahatani kentang di lokasi penelitian adalah sebesar Rp. 3.350.946,67 per luas tanam atau Rp.3.697.596,322 per hektar per musim tanam.

\section{Harga Jual}

Selain jumlah produksi, luas lahan, tenaga kerja dan modal maka harga jual produk juga merupakan faktor yang tidak kalah pentingnya dalam mempengaruhi besar kecilnya pendapatan usahatani. Rata-rata harga jual kentang di tingkat petani di lokasi penelitian adalah sebesar Rp. 3.275,$/ \mathrm{kg}$. Harga tersebut jauh lebih rendah dibandingkan dengan harga ditingkat konsumen pada waktu yang sama yaitu sebesar Rp. 6000,- $/ \mathrm{kg}$. 
Tabel 1. Nilai Estimasi Regresi Usahatani Kentang di Kecamatan Bukit Kabupaten Bener Meriah Tahun 2013

\begin{tabular}{clcrc}
\hline No. & \multicolumn{1}{c}{ Variabel } & Koefisien & t-hitung & Probabilitas (sig) \\
\hline 1. & Konstanta (a) & -1338 & -17.596 & .000 \\
2. & Produksi (Prod) & 570.497 & 9.415 & .000 \\
3. & Luas Lahan (Lh) & $1.657 \mathrm{E} 6$ & 1.742 & .094 \\
4. & Tenaga Kerja (TK) & -6590.069 & -1.572 & .129 \\
5. & Modal (Mdl) & .245 & 1.763 & .091 \\
6. & Harga (Hrg) & 346.580 & 17.820 & .000 \\
\hline & $* * *=$ signifikan pada $\alpha=0,01$ & \\
& R-square $=0,996$ & $* *=$ signifikan pada $\alpha=0,05$ & \\
F-sig $\quad=0,000$ & $*=$ signifikan pada $\alpha=0,10$ & \\
\hline
\end{tabular}

Tabel 1 memperlihatkan nilai koefisien determinasi $\left(\mathrm{R}^{2}\right)$ sebesar 0,996 . Hal ini berarti bahwa sebesar 99,90 persen variabel produksi, luas lahan, tenaga kerja, modal dan harga mampu menjelaskan variasi variabel pendapatan usahatani kentang. Dengan perkataan lain hubungan antara variabel independen dengan variabel dependen cukup kuat. Sedangkan sisanya hanya 0,4 persen dijelaskan oleh variabel lain yang tidak dimasukkan dalam model penelitian ini. Hal ini menunjukkan bahwa tidak banyak lagi faktor lain yang mempengaruhi pendapatan usahatani kentang di Kecamatan Bukit Kabupaten Bener Meriah.

Hasil estimasi juga memperlihatkan bahwa secara serempak variabel produksi, luas lahan, tenaga kerja, modal dan harga berpengaruh secara sangat signifikan berpengaruh terhadap pendapatan usahatani kentang yang ditunjukkan oleh nilai probability (probability value) F-test sebesar 0,000. Nilai probabilitas tersebut lebih kecil dari tingkat kepercayaan $(\alpha) 0,01$.

Sementara itu, secara parsial hanya variabel produksi dan harga yang berpengaruh sangat signifikan terhadap pendapatan yang ditunjukkan oleh nilai probability kedua variabel tersebut adalah 0,000 , nilai ini lebih kecil dari $\alpha=0,01$. Koefisien regresi variabel produksi sebesar 570.497,- yang menunjukkan bahwa jika produksi meningkat $1 \mathrm{~kg}$ maka pendapatan akan bertambah/meningkat sebesar Rp. 570.497. Implikasi dari temuan ini adalah bahwa pendapatan usahatani kentang masih bisa ditingkatkan melalui peningkatan produktivitas per hektar. Koefisien regresi 346.580, artinya jika terjadi kenaikan harga sebesar Rp.1 maka pendapatan akan meningkat sebesar Rp. 346.580,-. Implikasi dari temuan ini adalah pendapatan usahatani kentang masih bisa ditingkatkan jika harga ditingkat petani meningkat. Temuan ini ini sejalan dengan hasil penelitian yang dilakukan oleh Asni, $d k k$ (2010) yang menyimpulkan bahwa Pendapatan petani padi sawah nyata dipengaruhi oleh variabel jumlah produksi, harga jual, jumlah tenaga kerja dan modal secara bersama. Secara parsial, pendapatan petani padi sawah dipengaruhi oleh jumlah produksi dan harga jual.

Variabel luas lahan, tenaga kerja dan modal tidak signifikan mempengaruhi pendapatan dalam penelitian ini. Tidak signifikannya variabel luas lahan disebabkan produktivitas kentang di lokasi penelitian belum masih sangat rendah, sehingga untuk meningkatkan pendapatan masih bisa melalui peningkatan produktivitas belum perlu perluasan areal. Sementara tidak signifikannya variabel tenaga kerja disebabkan jumlah penggunaan tenaga kerja di lokasi penelitian terlalu sedikit sehingga yang ditunjukkan oleh kurang terawatnya tanaman di lapangan. Modal yang digunakan untuk usahatani kentang dalam penelitian ini belum berpengaruh terhadap pendapatan karena sebagian besar petani tidak menggunakan pupuk dan pemberantasan jika tanaman kentang diserang penyakit.

\section{KESIMPULAN DAN SARAN}

\section{Kesimpulan}

1. Produksi dan harga jual merupakan faktorfaktor yang berpengaruh sangat signifikan terhadap pendapatan usahatani kentang di Kecamatan Bukit Kabupaten Bener Meriah.

2. Rata-rata pendapatan usahatani kentang di Kecamatan Bukit Kabupaten Bener Meriah masih rendah. 


\section{Saran}

1. Produktivitas usahatani kentang di Kecamatan Bukit Kabupaten Bener Meriah masih sangat rendah. Oleh karena itu sedapat mungkin pemerintah daerah dan dinas terkait agar dalam perencanaan pengembangan usahatani kentang di tahun-tahun mendatang harus lebih banyak diarahkan kepada intensifikasi seperti lebih membekali petani tentang teknik budidaya secara benar dan intensif agar dapat meningkatkan produktivitas. Hal ini perlu dilakukan karena produksi merupakan salah satu faktor yang sangat mempengaruhi pendapatan usahatani kentang.

2. Harga jual ditingkat petani jauh lebih rendah dibandingkan harga konsumen, dan variabel harga sangat mempengaruhi rendahnya pendapatan usahatani kentang. Oleh karenanya maka pemerintah daerah dapat membuat kebijakan penetapan harga kentang di tingkat petani agar dapat membantu petani dalam meningkatkan pendapatan usahataninya.

\section{DAFTAR PUSTAKA}

Asni, Sya'ad. A., H. B. Tarmizi., \& Wahyu, A. P. (2010). Analisis produksi, pendapatan dan alih fungsi lahan di Kabupaten Labuhan Batu. Jurnal Mepa Ekonomi. Diakses dari http://jurnalmepaekonomi.blogspot.com/2010/ 05/analisis-produksi-pendapatan-dan$\underline{\text { alih.html }}$

Badan Pusat Statistik. (2011). PDB menurut lapangan usaha tahun 2010 (persen). Jakarta: BPS.

Direktorat Jenderal Hortikultura. (2011). Produksi sayuran nasional periode 2006 - 2010. Jakarta: Direktorat Jenderal Hortikultura.

Direktorat Jenderal Hortikultura. (2012). Komoditas unggulan. Jakarta: Direktorat Jenderal Hortikultura. Diakses dari http://hortikultura.deptan.go.id/?q=content/ko moditas-unggulan.

M. Nur H.I., Abdul Azis., \& M. Ramlan. (2010). Teknologi unggulan kentang rekomendasi BPTP NAD. Disampaikan pada Konsolidasi Perencanaan PUAP dan Persiapan Raker Litbang di BBP2TP Bogor, 12-14 Maret 2010 .

Soekartawi. (2002). Prinsip dasar ekonomi pertanian. Teori dan Aplikasi. (Edisi Revisi). PT. Raja Grafindo Perkasa, Jakarta. 